\title{
Comparison of Two PCR Methods in determining the Methicillin- Resistant Gene in Coagulase-Negative Staphylococci
}

\author{
Bokaeian M.1 PhD, Tahmasebi H.* MSc, Mohammadzadeh A.R. ${ }^{2}$ PhD, Adabi J.1 $M S c$, Sepehri Rad N. ${ }^{3}$ MSc
}

*Microbiology Department, Medicine School, Zahedan University of Medical Sciences, Zahedan, Iran 1Microbiology Department, Medicine School, Zahedan University of Medical Sciences, Zahedan, Iran 2Microbiology Department, Medicine School, Gonabad University of Medical Sciences, Gonabad, Iran 3Infectious Diseases \& Tropical Medicine Research Center, Zahedan University of Medical Sciences, Zahedan, Iran

\begin{abstract}
Aims: It is very important to detect the coagulase-negative Staphylococci, which produce the hospital infections. Being one of the most expensive and time-consuming stages before the polymerase chain reaction (PCR), DNA extraction is one of the primary stages of PCR. Then, it should be noticed that the elimination of the stage might save time and costs. The aim of this study was to compare two PCR methods including the method with the utilization of the extracted DNA with the extraction kit and the direct PCR method in the detection of the methicillin-resistant genes in the coagulase-negative Staphylococci.

Materials \& Methods: In the descriptive cross-sectional study, 135 Staphylococcus epidermidis and 88 Staphylococcus saprophyticus samples were studied, separated from blood, wounds, urinary catheter, and urine samples of patients hospitalized in the treatment centers of Zahedan. The direct PCR was done on the Staphylococcus saprophyticus and Staphylococcus epidermidis colonies. PCR with the extracted DNA was done for mecA and 16srDNA genes using the extraction kit, and the results were compared.

Findings: In both methods, mecA and 16srDNA genes were successfully amplified in $310 \mathrm{bp}$ and $420 \mathrm{bp}$ related to Staphylococcus bacteria identifying gene and methicillin resistant gene, respectively. In addition, there were approximately the same band qualities.

Conclusion: In order to save time and costs, the direct PCR method can be used to detect methicillin-resistant coagulase-negative Staphylococci.
\end{abstract}

\section{Keywords}

Staphylococcus epidermidis [http://www.ncbi.nlm.nih.gov/mesh/68013212];

Staphylococcus saprophyticus [http://www.ncbi.nlm.nih.gov/mesh/68057790];

Drug Resistance [http://www.ncbi.nlm.nih.gov/mesh/68004351];

Polymerase Chain Reaction [http://www.ncbi.nlm.nih.gov/mesh/68016133]

\footnotetext{
${ }^{*}$ Corresponding Author

Tel: +985433295744

Fax: +985433425732

Address: Microbiology Department, Medicine School, Zahedan University of Medical Sciences, Dr. Hesabi Square, Zahedan, Iran. Postal Code: 98167-43463

h.tahmasebi87@yahoo.com

Received: November 22, 2015 


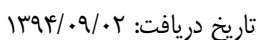

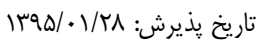

"نويسنده مسئول: h.tahmasebi87@yahoo.com
مقايسه دو روش PCR در تعيين زن مقاومت به متىسيلين در استافيلوكوكهاي كواتولاز منفى مونى

محمد بكائيان PhD

كروه ميكروب شناسى، دانشكده يزشكى، دانشكاه علوم بران بز شكى زاهدان، زاهدان،

ايران

MSc حامد طهماسبى

كروه ميكروب شناسى، دانشكده يزشكى، دانشخاه علوم يزشكى زاهدان، زاهدان،

علير ضا محمدزاده PhD

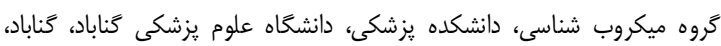

ايران

جواد ادبى MSc

كروه ميكروب شناسى، دانشكده يزشكى، دانشخاه علوم يزشكى زاهدان، زاهدان،

ايران

ناهيد سيهرى راد

مركر تحقيقات بيمارى عفونى - گرمسيرى، دانشخاه علوم يزشكى زاهدان،

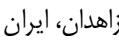

جكيده

اهداف: شناسايى استافيلوكوكهاى كوآكولازمنفى كه مسئول ايجاد

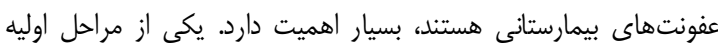
PCR وقت گيرترين و هزينهبرترين مراحل قبل از PCR است و با حذف آن آن مىتوان در زمان و هزينه صرفهجويى كرد. هدف از اين مطالعه، مقايسه

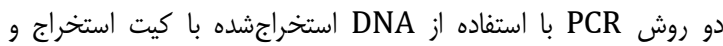

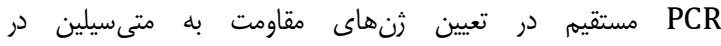
استافيلوكوكهاى كوآكو لازمنفى بود. مواد و روشها: در اين مطالعه توصيفى- مقطعى، هسا نمونه

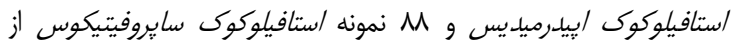
نمونههاى خون، زخه، سوند و كاتتر و ادرار بيماران بسترى دريل در مراكز

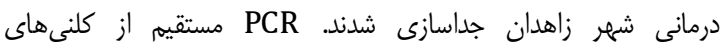

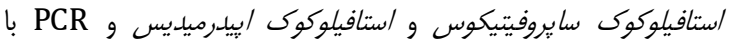
و استخراجشه توسط كيت استخراج براى زنهاى DecA DNA

16srDNA انجام شد و مورد مقايسه قرار كرفت.

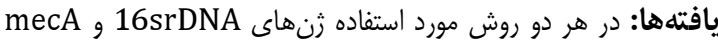

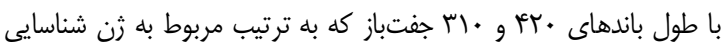
باكترى استافيلوكوى و ثن مقاومت به متى سيلين بودند، با موفقيت تكثير باني شدند و كيفيت باندهاى مشاهدهشده تقريباً برابر بود.

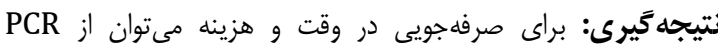

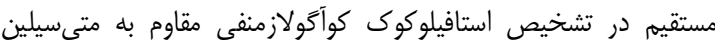

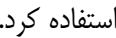
شناسايى اين ياتوزنها كه در ايجاد عفونتهاى بيمارستانى بسيار اهميت دارند، در بيشتر مواقع با روشهايى انجام مىشود كه داراى

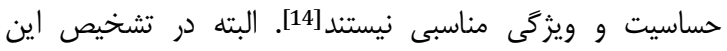

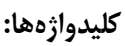

يلى مراز 
مقايسه دو روش PCR در تعيين ثن مقاومت به متى سيلين در استافيلوكوكهاى كواكولاز منفى ك.r.

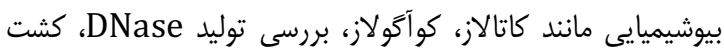

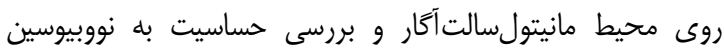
انجام گرفت. براساس CLSI (موسسه استانداردهاى آزمايشخاهى و

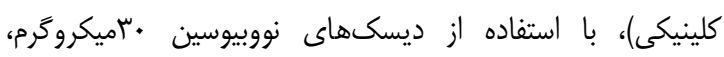

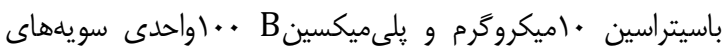

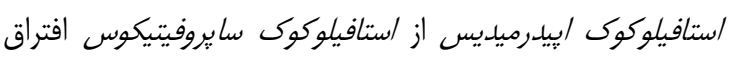

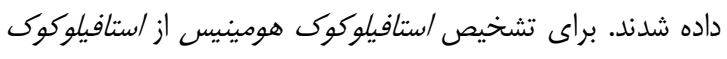

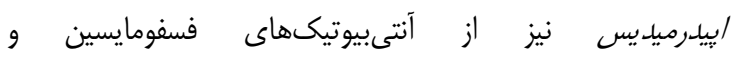

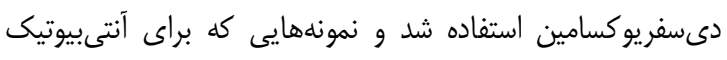

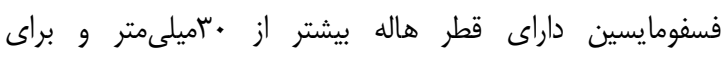
دىسفريوكسامين داراى قطر هاله بيشتر از ـاميلىمتر بودند،

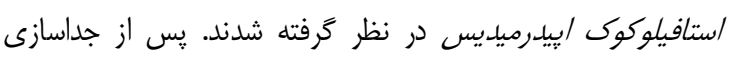

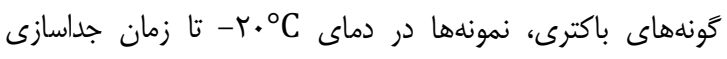

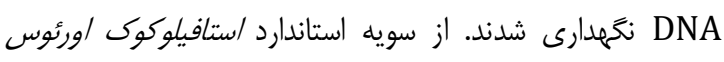
ATCC33591 بهنوان كنترل مثبت و از سويه استاندارد استافيلوكوك /ورئوس ATCC25923 بلهنوان كنترل منفى منيت استفاده شد.

استخراج DNA و كيفيتسنجى آنها: بdمنظور استخراج DNA بلادآكار, كشت داده شده و در دماى انكوبه شدند. سيس يك كلنى از هر ايزوله كشتدادهشده به به دمات

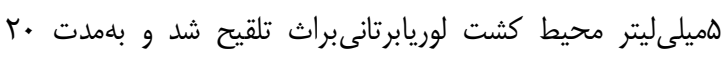

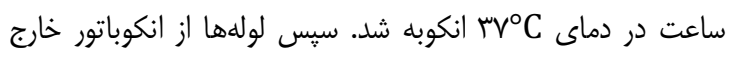

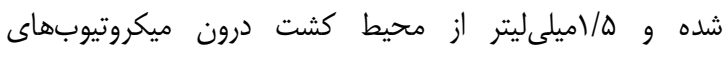

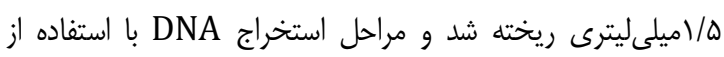

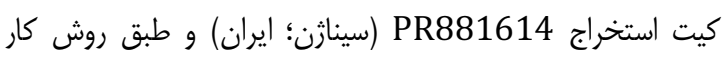
شركت سازنده انجام شد. براى بررسى كيفيت DNADاى استخراجشده، ابتدا با رقتسازى (د) قهاى استخراجشده، ODA

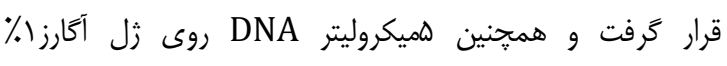

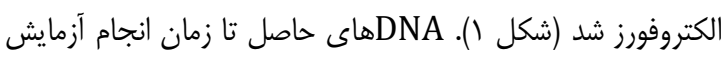

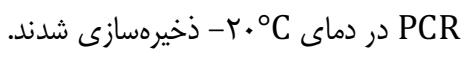

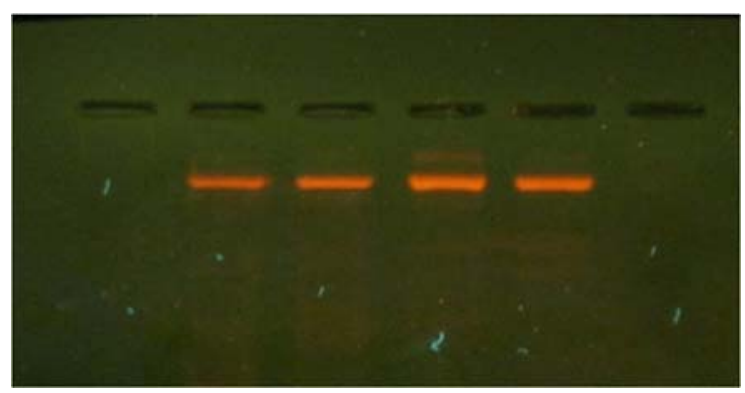

شكل () كيفيتسنجى و تاييد استخراج DNA باكترىهاى استافيلوكوى كوآكو لازمنفى توسط كيت استخراج
باكترىها و بعضاً سويههاى مقاوم، آزمونهاى دقيقى هم وجود

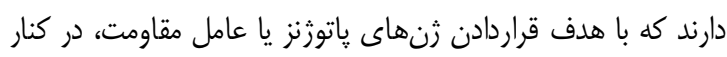
سرعت از دقت بالايى برخوردارند، اما بهدليل هزينه بالايى كه دارند

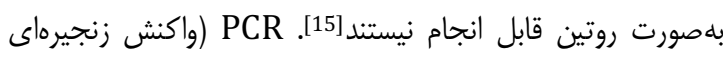
يلىمراز) يكى از حساسترين و دقيقترين روشهاى مولكولى است كه مىتواند براى رديابى ثنهاى مختلف در مولكول DNA إلى مورد

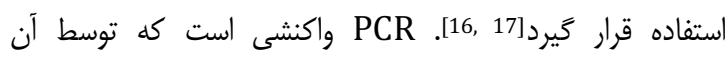
مىتوان بهطور مصنوعى و در شرايط آزمايشگاهى ثن خاصى راد در

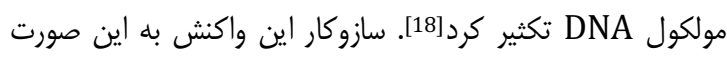

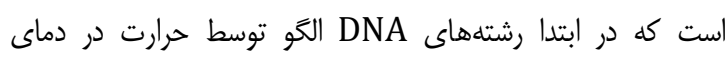
ه $90^{\circ} \mathrm{C}$ يرايمر در دمايى خاص، همانندسازى انجام مىشود [19]. در

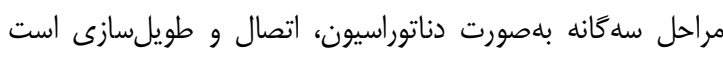
كه دما و مدتزمان هر مرحله و تعداد سيكلهاى تكرارشونده، با هم متفاوت است [5]. يكى مراحل PCR، آمادهسازى و استخراج DNA مئفاوت است. اين كار

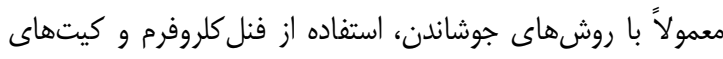
استخراج انجام مىشود و از طرفى PCR با استفاده از استخراجشده در برخى موارد علاوه بر تحميل هزينههاى مالى إنى

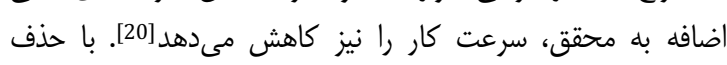

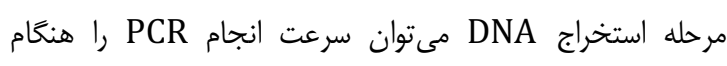

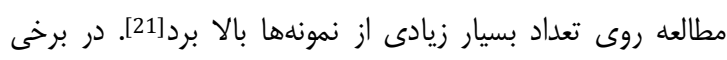

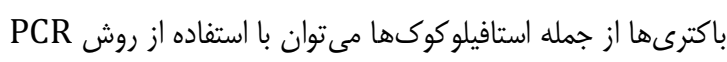

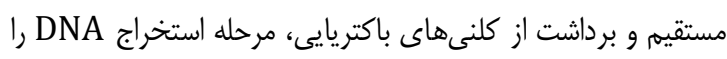
حذف كرد. با توجه به اهميت PCR براى تشخيص سريع و دقيق، هدف از اين

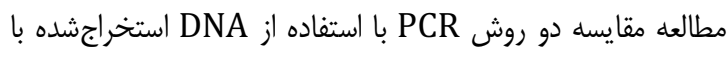
كيت استخراج و PCR مستقيم در تعيين زنهاى مقاومت به متىسيلين در استافيلوكوكهاى كوآَّولازمنفى بود.

\section{مواد و روشها} جداسازى نمونهها: در اين مطالعه توصيفى - مقطعى كه طى

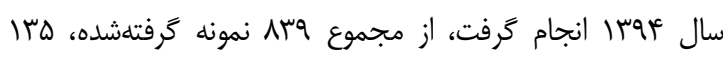

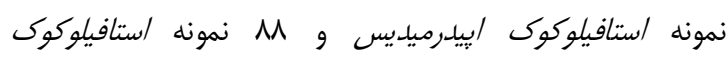
سايروفيتيكوس از نمونههاى خون، زخم، سوند و كاتتر و ادرار

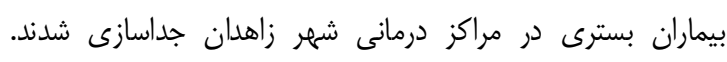

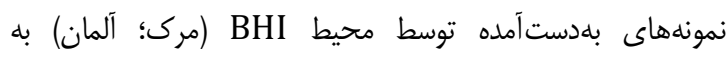

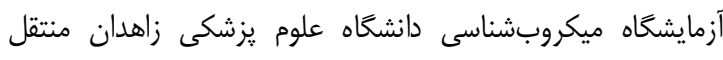

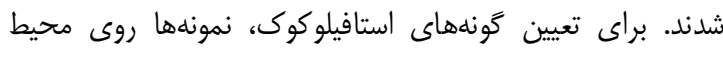

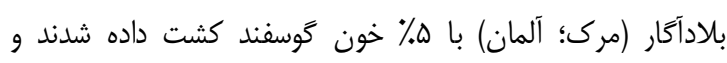

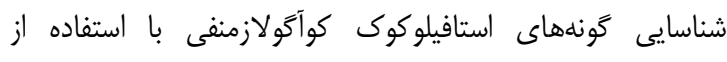
روشهاى تشخيص ميكروبى از قبيل رنتىآميزى گرم، آزمونهاى 
شناسايى باكترى استافيلوكوى و زن مقاومت به متىسيلين بودند، با

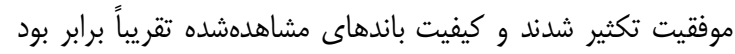

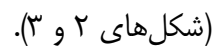

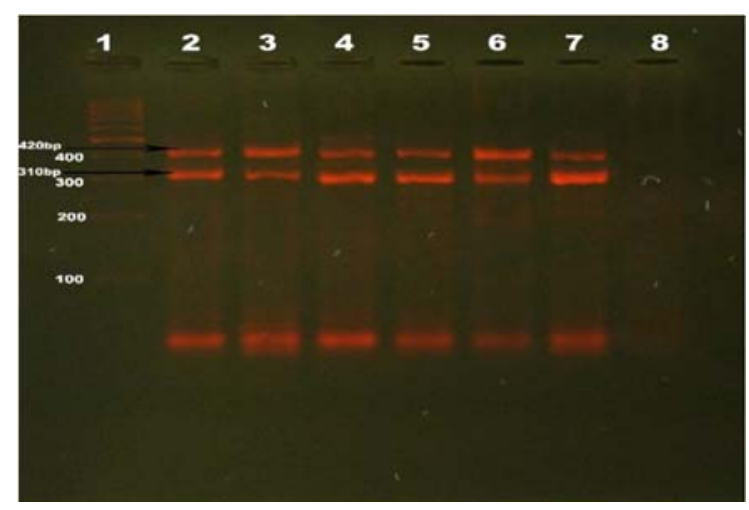

شكل r) الكتروفورز محصول PCR استافيلوكوكهاى كوآكولازمنفى با استفاده

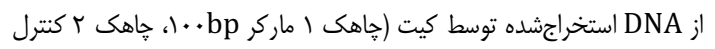

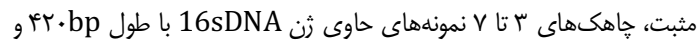

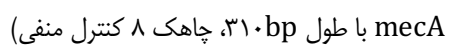

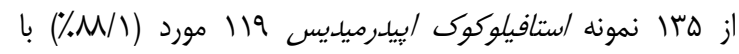
روش PCR با استفاده از DNA استخراجشده توسط كيت استخراج

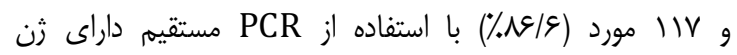
V) بودند، و از MecA

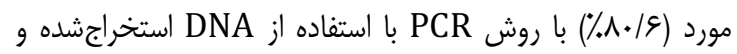

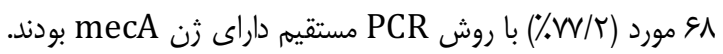

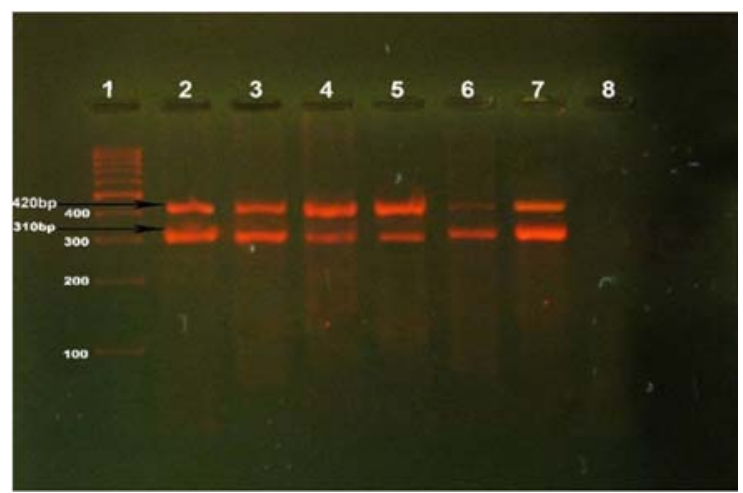

شكل س) الكتروفورز محصول PCR مستقيم استافيلوكوكهاى كو آكَولازمنفى با

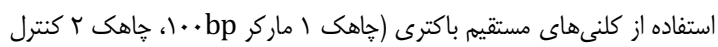

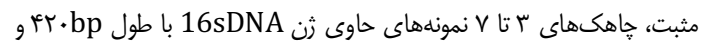

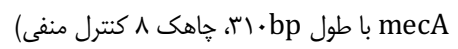

\section{بحث}

تشخيص باكترىهاى عامل بيمارى و در كنار آن، مشخصكردن

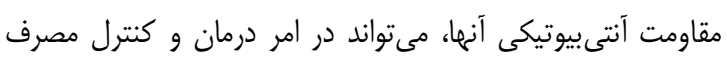

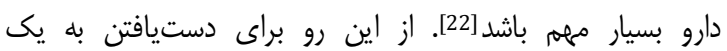
تشخيص مطمئن و بلهرفه، بايد از روشهاى حساس استفاده كرد.
در روش PCR مستقيه، بلجاى استخراج DNA و مو انجام مراحل

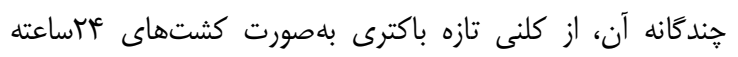

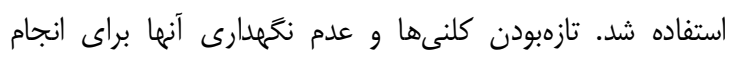
را بايد مورد نظر قرار داد. PCR

\section{انجام PCR با DNA استخراجشده و PCR مستقيم:}

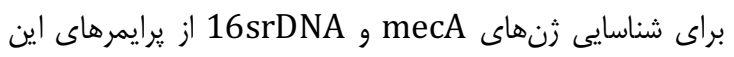

$$
\text { ثنها استفاده شد (جدول () ). }
$$

\begin{tabular}{|c|c|c|}
\hline \multicolumn{3}{|c|}{ 16sDNA و جدول () يرايمرهاى ثنهاى mecA } \\
\hline 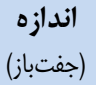 & طول توالى & يرايمرها \\
\hline \multirow{2}{*}{ Ft. } & CAGCTCGTGTCGTGAGATGT & 16SrDNA-F \\
\hline & AАTCATTTGTCCСАCСТTCG & 16SrDNAR \\
\hline \multirow{2}{*}{ 部. } & CCTAGTAAAGCTCCGGAA & mecA-F \\
\hline & CTAGTCCATTCGGTCCA & mecA-R \\
\hline
\end{tabular}

بلمنظور انجام واكنش PCR، حجم نهايى هזميكروليتر شامل؛

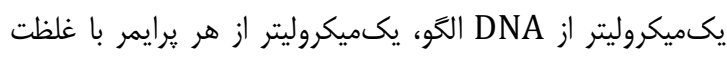

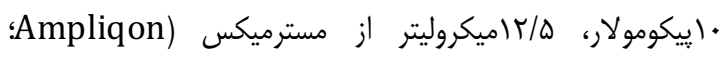

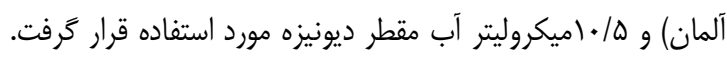
از مخلوط PCR فاقد DNA الخو بdعنوان كنترل منفى استفاده

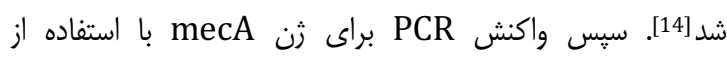
دستخاه ترموسايكلر (BioRad؛ ايالات متحده)، شامل دناتوراسيون اوليه در 9 C C بهمدت ه دقيقه، هץ سيكل دناتوراسيون در دماى (

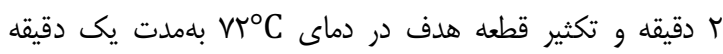
انجام گرفت. برنامه PCR براى زن 16srDNA مشابه ثن انجام شد. محصولات PCR براى انجام الكتروفورز، در درن يخجال در دماى

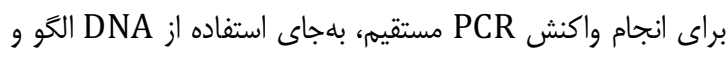

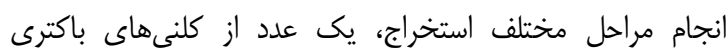

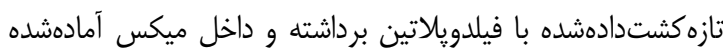

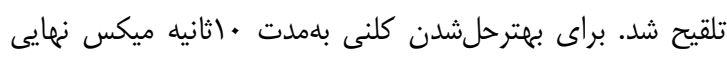

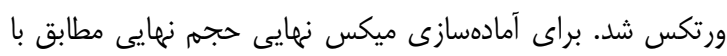
روش اول به هזميكروليتر رسانده و بهجاى يكميكروليتر از هر

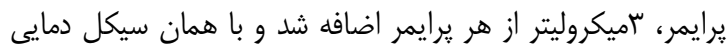
واكنش انجام گرفت.

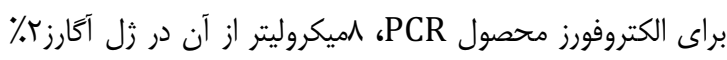

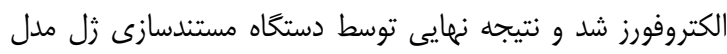

$$
\text { CCD-Tab1 }
$$

\section{يافتهها}

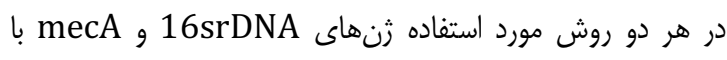

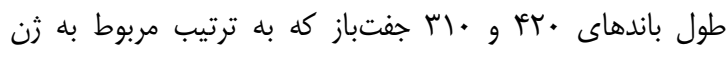

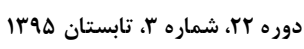
فصلنامه افق دانش 


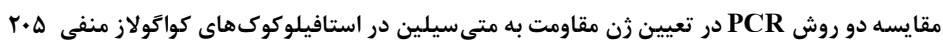

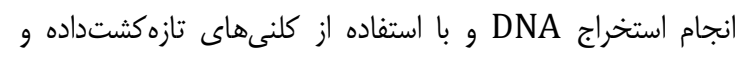

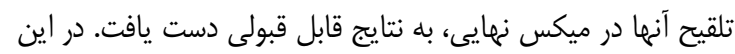

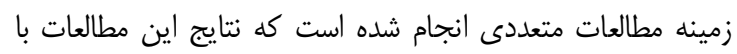

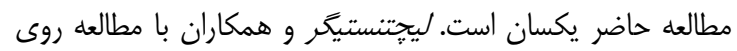

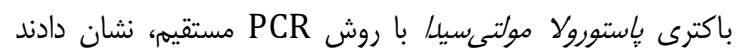

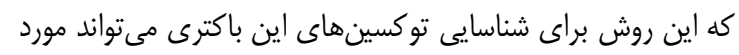

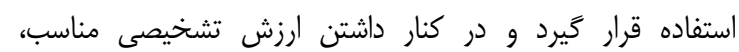

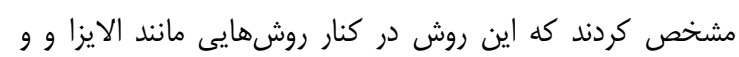

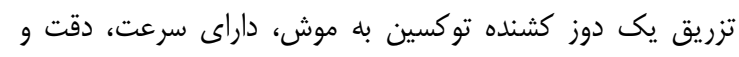

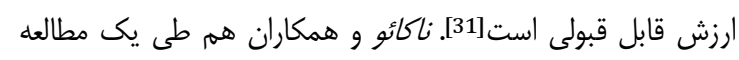

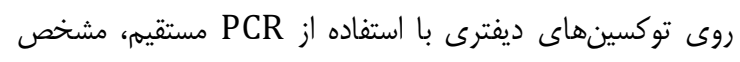

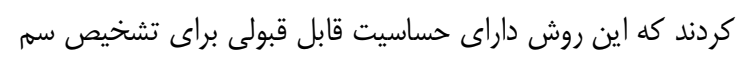

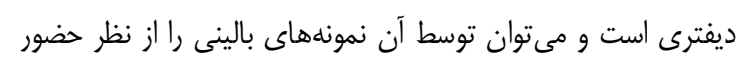

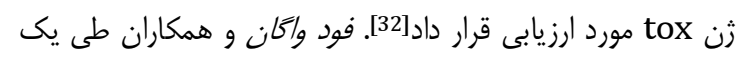
مطالعه از روش PCR مستقيم براى ارزيابى باكترى /شريشيا كلى فو

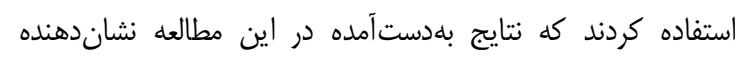

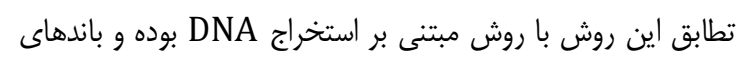

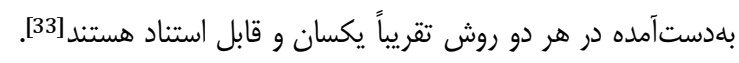

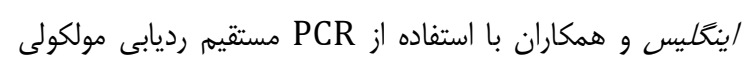

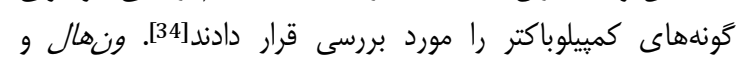

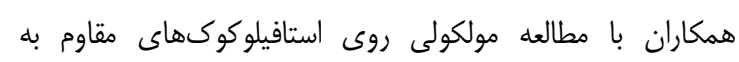

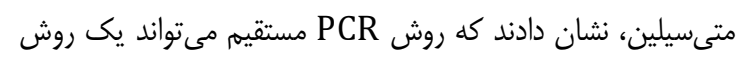
مناسب در تشخيص اين باكترىها باشد، بلطورى كه حساسيت و

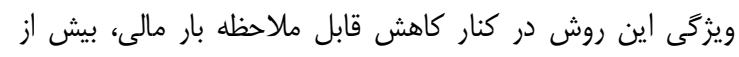

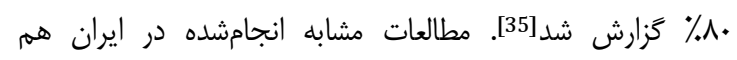

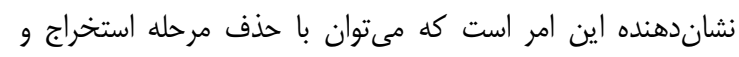

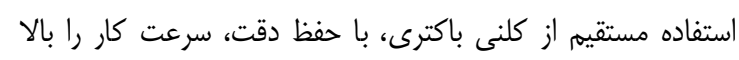

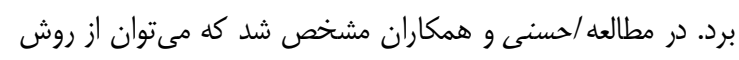

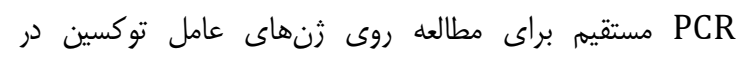

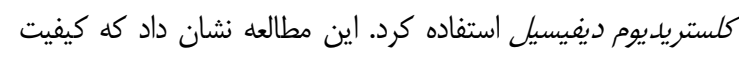
باندهاى بلدستآمده در اين روش با كيفيت باندهاى بلددست آمده

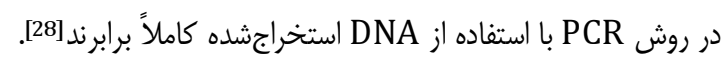

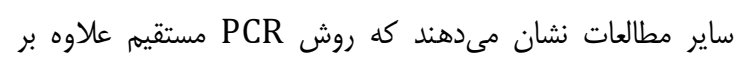

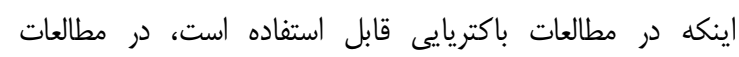

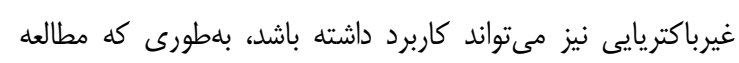

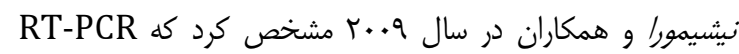

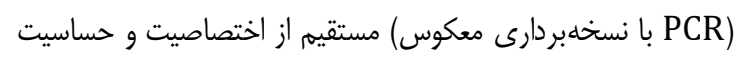

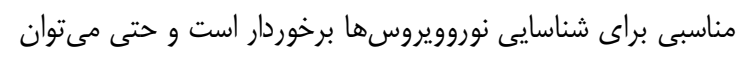
از اين روش براى بررسى حضور نوروويروس در مدفوع نيز استفاده

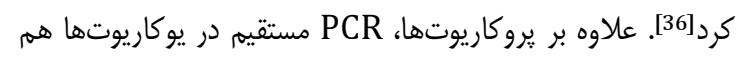

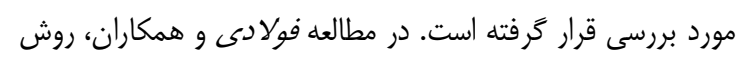
مستقيه و ساير روشها براى تشخيص ليشمانيوز جلدى مورد
يكى از بهترين و سريعترين روشهاى ممكن براى اين كار، شناسايى ثنهاى كدكننده اين عوامل است كه با حساسيت بسيار

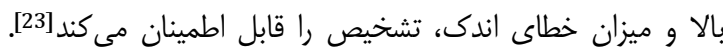

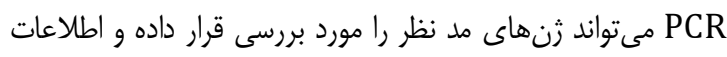

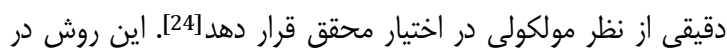

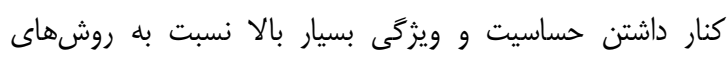

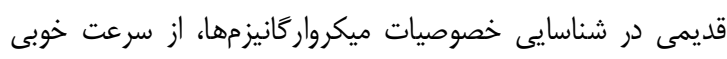

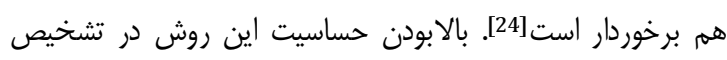

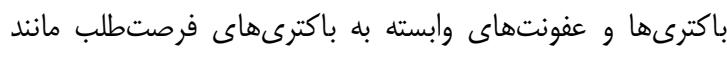

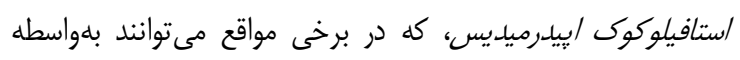
وسايل يزشكى و آلودگى هاى سطوح بيمارىهاى شديلى شيدى رئى را ايجاد

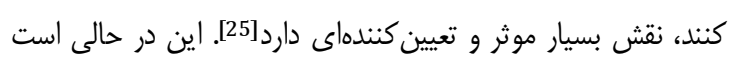

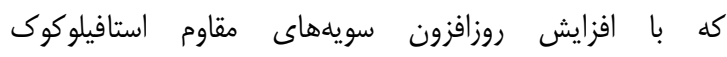

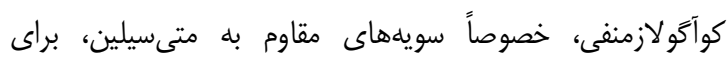
تشخيص سريع و جلوگيرى از گسترش سويههاى مقاوم بايد به روشهاى سريع و قابل اطمينان روى آورد[25]. با استفاده از روشهاى فنوتييى و سرولوزيكال نمىتوان فوابن عوامل

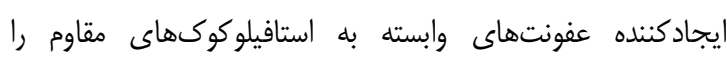

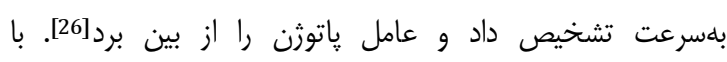
مشخص كردن ويزگى هاى ذاتى يا اكتسابى باكترى بيمارىزا، از باتوزي

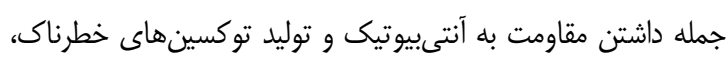

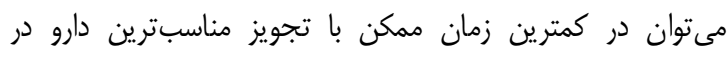

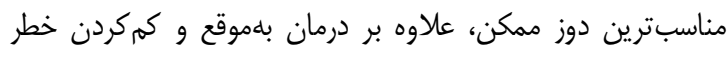

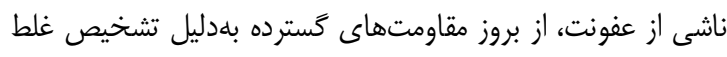
و تجويز اشتباه نيز جلوگيرى كرد[27. اگر خه PCR يك روش ساده، آسان و دردسترس براى تكثير زنوم است، اما به استخراج DNA كه يك مرحله وقت دارد. براى رسيدن به بهترين نتايج در فرآيند PCR بايد كيفيت

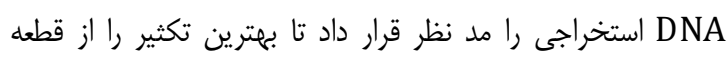

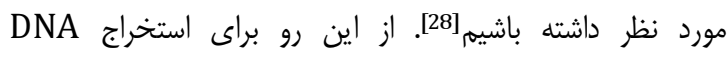
روشهاى متفاوتى از جمله جوشاندن، فنل كلروفرم، رسوب با اتانول،

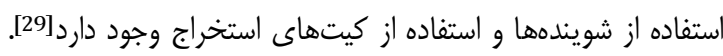
هر يك از اين روشها در كنار وقت گيربودن و تحميل هزينه جانبى،

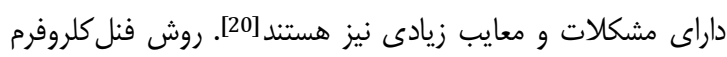

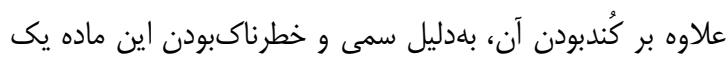

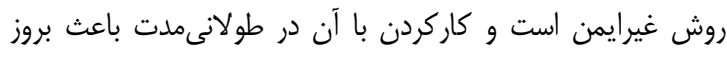

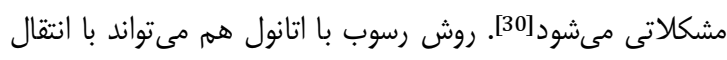

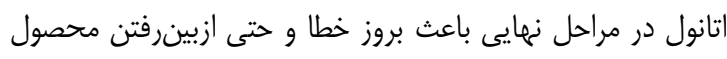

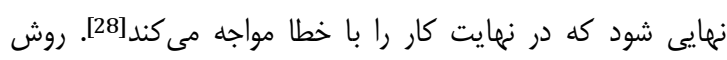

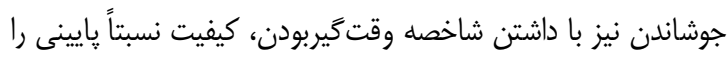
از استخراجشده عرضه مى كند [25].

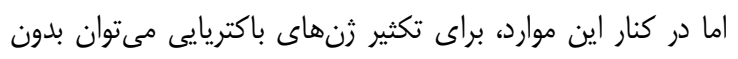




\author{
منابع مالى: اين يزوهش با حمايت مالى معاونت محترم تحقيقات

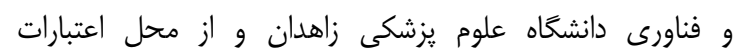 \\ طرحهاى تحقيقاتى صورت كرفت.
}

منابع

1- Inweregbu K, Dave J, Pittard A, Nosocomial infections. Contin Educ Anaesth Crit Care Pain. 2005;5(1):14-7.

2- Martin MA, Pfaller MA, Wenzel RP. Coagulase-negative staphylococcal bacteremia: Mortality and hospital stay. Ann Intern Med. 1989;110(1):9-16.

3- Cheung GY, Otto M. Understanding the significance of Staphylococcus epidermidis bacteremia in babies and children. Curr Opin Infect Dis. 2010;23(3):208-16.

4- Schwalbe RS, Stapleton JT, Gilligan PH. Emergence of vancomycin resistance in coagulase-negative staphylococci.. N Engl J Med. 1987;316(5):927-31.

5- Rupp ME, Archer GL. Coagulase-negative staphylococci: Pathogens associated with medical progress. Clin Infect Dis. 1994;19(2):231-43.

6- Huebner J, Goldmann DA. Coagulase-negative staphylococci: Role as pathogens. Ann Rev Med. 1999;50(1):223-36.

7- Rupp ME, Archer GL. Coagulase-negative staphylococci: Pathogens associated with medical progress. Clin Infect Dis. 1994;19(2):231-43.

8- Makki AR, Sharma S, Duggirala A, Prashanth K, Garg P, Das T. Phenotypic and genotypic characterization of coagulase negative staphylococci (CoNS) other than Staphylococcus epidermidis isolated from ocular infections. Invest Ophthalmol Vis Sci. 2011;52(12):901822.

9- Raei F, Eftekhar F. Studying the presence of blaZ gene and betalactamase production in clinical isolates of Staphylococcus epidermidis. Iran J Med Microbiol. 2008;2(2):35-41.

10- Maskell R. Importance of coagulase-negative staphylococci as pathogens in the urinary tract. Lancet. 1974;1(7867):1155-8.

11- Uçkay I, Harbarth S, Ferry T, Lübbeke A, Emonet S, Hoffmeyer $\mathrm{P}$, et al. Meticillin resistance in orthopaedic coagulase-negative staphylococcal infections. J Hosp Infect. 2011;79(3):248-53.

12- Klingenberg C, Aarag E, Rønnestad A, Sollid JE, Abrahamsen TG, Kjeldsen G, et al. Coagulase-negative staphylococcal sepsis in neonates. Association between antibiotic resistance, biofilm formation and the host inflammatory response. Pediatr Infect Dis J. 2005;24(9):817-22.

13- Mombach Pinheiro Machado AB, Reiter KC, Paiva RM, Barth AL. Distribution of staphylococcal cassette chromosome mec (SCCmec) types I, II, III and IV in coagulase-negative staphylococci from patients attending a tertiary hospital in southern Brazil. J Med Microbiol. 2007;56(10):1328-33.

14- Park JY, Fox LK, Seo KS, McGuire MA, Park YH, Rurangirwa FR, et al. Comparison of phenotypic and genotypic methods for the species identification of coagulase-negative staphylococcal isolates from bovine intramammary infections. Vet Microbiol. 2011;147(2):142-8.

15- Zadoks RN, Watts JL. Species identification of coagulase-negative staphylococci: genotyping is superior to phenotyping. Vet Microbiol. 2009;134(1-2):20-8.

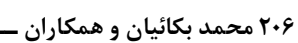

مقايسه قرار كرفته است[37].

با توجه به مقطعىبودن اين مطالعه و عدم وجود زمان كافى براى

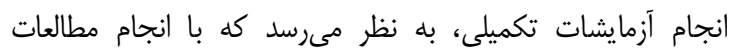

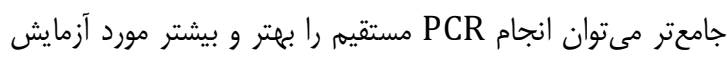
قرار داد. با ازبينبردن نتايج كاذب (مثبت و منفى) علاوه بر اينكه

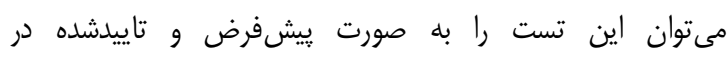

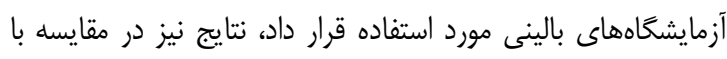

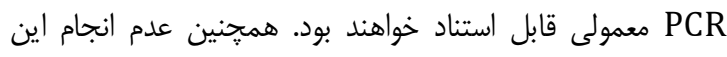

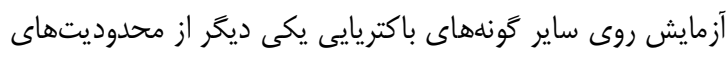

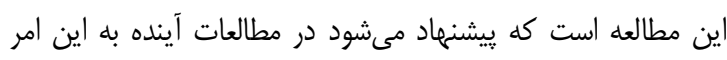
يرداخته شود. براساس نتايج بلهستآمده مىتوان كفت با توجه به وقت گيربودن مراحل استخراج DNA و يرهزينهبودن برخى كيتهاى استخراج

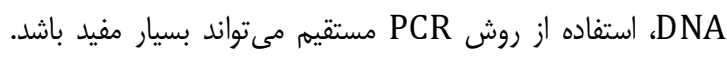

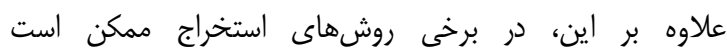

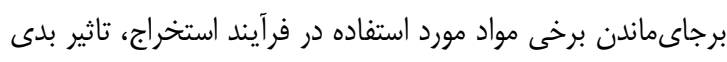

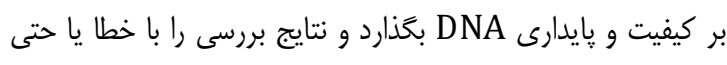

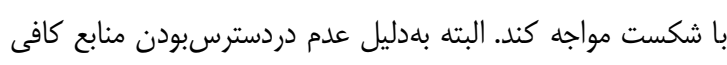
و نتايج مورد بررسى براى ساير باكترىها از خانوادههاى مختلف

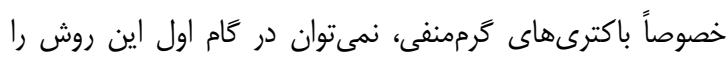

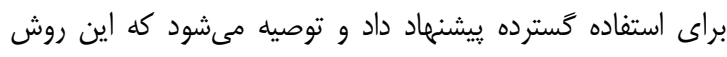
روى ساير باكترىها از جنسهاى مختلف نيز انجام شود. اما با بانئن

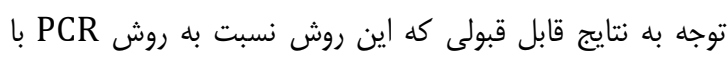
قاستخراجشده داشت، توصيه مىشود كه در مواردى كه له قطعيت آنها اثبات شده است، از كلنى مستقيم براى انجام آزمايشات PCR

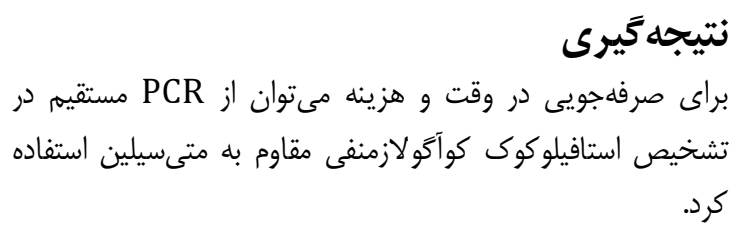

تشكر و قدردانى: نويسندكان اين مقاله بر خود لازم مىدانند از مسئولان مركز تحقيقات بيمارىهاى عفونى - ترمسيرى دانشخاه

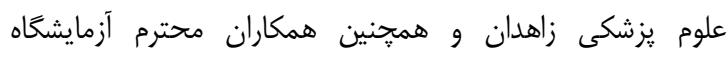

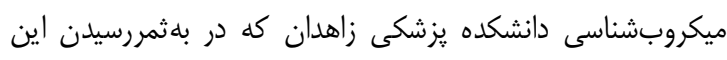
ثروهش ياريخر بودند، تشكر نمايند.

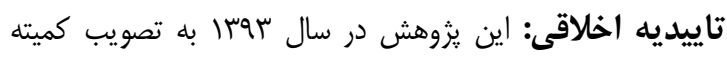
اخلاق و يثوهشهاى علمى دانشگاه علوم يزشكى زاهدان رسيد.

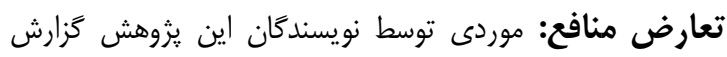
نشده است. دوره rז، شماره r، تابستان هو فصلنامه افق دانش 


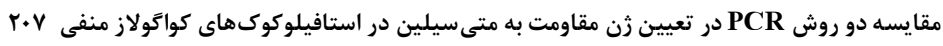

28- Ahsani MR, Shamsaddini BM. Compare of two methods of direct PCR and PCR with DNA extraction in Clostridium Perfringens typing. Iran Vet J. 2012;8(4):512.

29- Mousazade Moghadam M, Babavalian H, Mirnejad R, Shakeri F. Rapid DNA extraction of bacterial genome of Staphylococcus aureus using laundry detergents and assessment of the efficiency of DNA in downstream process using PCR. Med Lab J. 2012;6(1):35-42.

30- Eickbush TH, Moudrianakis EN. The histone core complex: An octamer assembled by two sets of proteinprotein interactions. Biochem. 1978;17(23):4955-64.

31- Lichtensteiger CA, Steenbergen SM, Lee RM, Polson DD, Vimr ER. Direct PCR analysis for toxigenic Pasteurella multocida. J Clin Microbiol. 1996;34(12):3035-9.

32- Nakao H, Popovic T. Development of a direct PCR assay for detection of the diphtheria toxin gene. J Clin Microbiol. 1997;35(7):1651-5.

33- Fode-Vaughan KA, Maki JS, Benson JA, Collins ML. Direct PCR detection of Escherichia coli 0157:H7. Lett Appl Microbiol. 2003;37:239-43.

34- Inglis GD, Kalischuk LD. Use of PCR for direct detection of Campylobacter species in bovine feces. Appl Environ Microbiol. 2003;69(6):3435-47.

35- van Hal SJ, Stark D, Lockwood B, Marriott D, Harkness J. Methicillin-resistant Staphylococcus aureus (MRSA) detection: comparison of two molecular methods (IDI-MRSA PCR assay and GenoType MRSA Direct PCR assay) with three selective MRSA agars (MRSA ID, MRSASelect, and chromagar MRSA) for use with infection-control swabs. J Clin Microbiol. 2007;45(8):2486-90.

36- Nishimura N, Nakayamaa H, Yoshizumib S, Miyoshib M, Tonoikea $\mathrm{H}$, Shirasakia $\mathrm{Y}$, et al. Detection of noroviruses in fecalspecimens by direct RT-PCR without RNA purification. J Virol Methods. 2010;163(2):282-6.

37- Fazaeli A, Fuladi B, Hashemi Shahri M, Sharifi I. Evaluation of a direct PCR in comparison with routine microscopy and in vitro culture for diagnosis of cutaneous leishmaniasis. Iran J Public Health. 2007;36(Suppl 1):1-2.
16- Andreson R, Reppo E, Kaplinski L, Remm M. Genomemasker package for designing unique genomic PCR primers. Bio Med Clin Bioinform. 2006;7:172.

17- Walley AJ. PCR protocols: current methods and applications. J Med Genet. 1994;31(1):87.

18- Ottens R, Templeton J, Paradiso V, Taylor D, Abarno $D$, Linacre A. Application of direct PCR in forensic casework. Forensic Sci Int Genet Suppl Ser. 2013;4(1):e47-8.

19- Rychlik W. Selection of primers for polymerase chain reaction. Methods Mol Biol. 1993;15:31-40.

20- Shahbazi B. Narenji H. Comparison of four methods of DNA extraction from gram-negative and gram-positive bacteria. Zanko J Med Sci. 2014;15(45):9-16.

21- Chum PY, Haimes JD, André CP, Kuusisto PK, Kelley ML. Genotyping of plant and animal samples without prior DNA purification. J Vis Exp. 2012;10(67):37913844.

22- Fiebelkorn KR, Crawford SA, McElmeel ML, Jorgensen JH. Practical disk diffusion method for detection of inducible clindamycin resistance in Staphylococcus aureus and coagulase-negative staphylococci. J Clin Microbiol. 2003;41(10):4740-4.

23- Capoluongo E, Giglio A A, Lavieri MM, Lesnoni-La Parola I, Ferraro C, Cristaudo A, et al. Genotypic and phenotypic characterization of Staphylococcus aureus strains isolated in subjects with atopic dermatitis. Higher prevalence of exfoliative B toxin production in lesional strains and correlation between the markers of disease intensity and colonization density. J Dermatol Sci. 2001;26(2):145-55.

24- Raeymaekers L. Basic principles of quantitative PCR. Mol Biotechnol. 2000;15(2):115-22.

25- Borst P. Genetic mechanisms of drug resistance: A review. Acta Oncol. 1991;30(1):87-105.

26- Montazeri EA, Khosravi AD, Jolodar A, Ghaderpanah M, Azarpira S. Identification of methicillin-resistant Staphylococcus aureus (MRSA) strains isolated from burn patients by multiplex PCR. Burns. 2015;41(3):5904.

27- Quirk M. First VRSA isolate identified in USA. Lancet Infect Dis. 2002;2(9):510. 